\title{
Peer editing as a way of developing ELT students' writing skills: An action research
}

\author{
Erkan Yüce $^{a *}$ (iD), Bengü Aksu Ataç ${ }^{b}$ \\ ${ }^{a}$ Nevşehir Hacı Bektaş Veli University, Nevşehir, 50300, Turkey \\ ${ }^{b}$ Nevşehir Hacı Bektaş Veli University, Nevşehir, 50300, Turkey
}

\section{APA Citation:}

Yüce, E., \& Aksu Ataç, B. (2019). Peer editing as a way of developing ELT students' writing skills: An action research. Journal of Language and Linguistic Studies, 15(4), 1226-1235.

Submission Date:31/10/2019

Acceptance Date:10/12/2019

\begin{abstract}
Inspired from problematic nature of writing, this study adopted an action research through peer editing as a way of developing writing skills of students at an ELT department. This study was designed through the specific stages of an action research which are planning, action, observation and reflection. In planning and action stages, the researchers designed general and specific criteria to follow during the cycles, and they applied these criteria accordingly. In observation stage, the peer editing processes in specific cycles were observed. The researchers used cycles at this stage. These cycles were application processes which were followed step by step during peer editing. In reflection stage, reflections of the participants on peer editing in writing classes were gathered through a form. Qualitative data collected from participants were analyzed and reported descriptively at the end. The reflections were categorized as before and after writing classes, advantages and disadvantages of peer editing. In conclusion, peer editing in writing classes affects foreign language learners positively, and peer editing can be used in writing classes as an alternative way of developing ELT students' writing skills.
\end{abstract}

(C) 2019 JLLS and the Authors - Published by JLLS.

Keywords: peer editing; action research; writing skill; ELT

\section{Introduction}

\subsection{Problem}

Writing as a productive language skill has been regarded by many as a difficult one in comparison to other language skills, which are speaking, listening, and reading (Hengwichitkul, 2009; Rattanadilok Na Phuket \& Othman, 2015; Reid, 2002; Sermsook, Liamnimitr \& Pochakorn, 2017; Watcharapunyawong \& Usaha, 2013). Writing in a second or foreign language becomes a complicated process as it comprises both cognitive strategies and background knowledge on the target language in terms of genre, culture, values etc. (Polio \& Williams, 2009), and many factors may affect language users' writing in a target language (Kobayashi \& Rinnert, 2008; Kubota, 1998). Moreover, writing

\footnotetext{
* Corresponding author. Tel.: 0 (384) 2281000

E-mail address: erkanyuce@nevsehir.edu.tr
} 
requires a profound understanding of the text as a process, since reaching immediate feedback to form a frame to follow in writing may not always be possible, and language users may be required to write comprehensible, clear, suitable and informative texts. Using target language accurately, presenting and organizing ideas clearly hold a crucial place in writing process in order to fulfill communication needs successfully (Olshtain, 2001). In addition to the aforementioned problematic nature of writing, there are also many reasons a student may avoid writing since most of the students think that writing is not fun or enjoyable. When writing is not meaningful, it is really difficult to collect the variety of skills needed to develop enthusiasm about writing. In order to reduce the frustration, struggles and sense of threat that students may have about writing, peer editing can be benefited. Enhancing writing skills could be achieved by adopting more meaningful tasks or common practices through peer editing.

\subsection{Peer Editing}

Peer editing (or peer response) is a common practice applied to enhance writing skills of language learners in language classes. More than a decade, there have been research studies on the influence of peer editing in foreign or second language writing instruction (Polio \& Williams, 2009). That is to say, peer editing is a strategic source in effective writing process.

It seems to be valuable to model, teach and control peer editing in language classrooms as nonnative speakers may have insufficient competence of the target language to give instant feedback to the papers written by their classmates (Kroll, 2001). Many students may find editing and revision stages of writing boring and frustrating. At this point, peer editing can improve students' interests and enthusiasms for revision processes during writing. The influence of peer editing on language learners' performances have been searched in terms of time, quality of writing, learners' attitudes on the advantages of peer editing and correction types by peers (Polio \& Williams, 2009). As for the teachers of writing, it is a diagnostic teaching tool that unifies the class. Language teachers can gain insights into students' cognitive skills as well as linguistic skills through their editorial comments.

Guiding peer editing can be conducted by teachers via presenting a list of straightforward questions which requires students' attention while they review both their own and their peers' writings. Initial classroom exercises can engage language learners in evaluating papers through a checklist pointing specific aspects, which may have been covered in classes (Kroll, 2001). The important stages in peer editing such as compliments, suggestions and corrections should be emphasized by teachers and peers in an encouraging and positive manner.

\subsection{Importance of the Study and Research Questions}

This study focused on writing problems of prospective foreign language teachers studying at an English Language Teaching (ELT) department of a public university in Turkey. The study can be regarded as an important one when we consider the context of the study. The study was conducted at an ELT department and the participants were prospective ELT teachers. Developing their writing skills as well as other language skills holds crucial importance in their professional development. Additionally, the department is relatively a new one when we consider the other ELT departments at different universities in terms of their establishment years. Within this context, this kind of applications would contribute to the efficiency of the language classes by presenting valuable conclusions, and content of writing classes can be reviewed in a way that helps prospective ELT teachers' both individual and professional developments. In this regard, there are two research questions in the study as:

1.What are the reflections of participants on peer editing before and after the writing classes?

2.What are the reflections of participants on peer editing regarding its advantages and disadvantages? 


\subsection{Literature Review}

Peer editing has been addressed in the literature by many studies on various aspects of foreign or second language teaching (Sadeghi \& Baneh, 2012; Amores, 1997; Byrd, 2003; Harutyunyan \& Poveda, 2018; Min \& Xuemei, 2016; Strijbos, Narciss \& Dünnebier, 2010). The following paragraphs discuss several of them in line with the context of this study.

Firstly, the literature reported research studies which investigated language learners' and language teachers' perceptions on peer editing. For example, Finch (2014) investigated student and teacher perceptions on peer editing at an English program at a university context in Korea through a focus group interview and questionnaire. The findings indicated that the participants had consensus on the advantages of peer editing. Similarly, Harutyunyan and Podeva (2018) searched the feelings and expectations of beneficiaries on peer review through the perceptions of students at a university context in Ecuador. The participants experienced peer revision as the main tool in an academic writing course to improve their final writing assignments. The results indicated that the participants who had undertaken a peer revision approach to academic writing thought that they benefited from peer revisions. These studies in two different contexts indicated that both language learners and professionals had positive attitudes towards peer editing. Secondly, error analysis processes were conducted in several research studies to develop writing skills of language learners. For instance, Zafar (2016) tried to improve writing skills of second language learners through error analysis in written tasks. The study suggested using error analysis to enhance language learners' communication skills in bilingual settings. Additionally, Sermsook et al. (2017) examined language errors of learners studying English at a Thai university context by analyzing written samples of the students. The results showed that negative transfer of certain aspects of students' mother language to the target language can result in writing problems in terms of spelling, subject-verb agreement, punctuation, articles, and capitalization. The study implied the application of explicit feedback on writing errors of students. Thirdly, experimental designs were performed to see the effects of peer editing on students' writing abilities. Diab (2010) tried to compare peer editing and self-editing by implementing an experimental study on two different groups. It was observed that rule-based errors decreased significantly after the revisions in the experimental group. The study suggested peer editing in writing classes for language development. Likewise, Behjat and Yamini (2012) investigated whether assignment of self-editing and peer editing could improve EFL writing skills of Iranian university students. They designed an application consisting pre- and post-test methods in two different learner groups. The results showed that both self-editing and peer editing improved students' EFL writing skills. Additionally, Ruegg (2015) tried to define the influence of teacher and peer response on learners' writing performances. The participants received different treatments in two different groups throughout an academic year. The results suggested that it would be more appropriate for peers to provide feedback regarding academic and organization style, while teachers give feedback regarding content and grammar. Lastly, the influence of different instruction types on writing skills were also investigated in language education contexts. Ekmekci (2017) revealed the influence of flipped instruction in language learning regarding writing skill. The study compared flipped writing classes and conventional writing classes with regard to students' writing performances. The findings yielded that students in the flipped writing classes outscored students in the conventional writing classes in terms of their writing performances after treatments. Similarly, Göy (2017) investigated the impact of strategy instruction on self-regulation abilities and writing skills of foreign language learners. The data were collected via multiple sources from the participants. The results indicated that students could improve their writing skills through strategy training. In conclusion, the literature showed many research studies exploring relations between peer editing and writing, and practices which were conducted by professionals to improve language learners' writing ability in language education contexts. 


\section{Method}

\subsection{Setting and Participants}

The present study was completed at an ELT department of a public university in Turkey. The department was a comparatively new one, when its establishment year, 2013, is considered. The study was conducted in the spring term of 2017-2018 academic year, and the name of course was 'Reading \& Writing Skills II'. The course was for the $1^{\text {st }}$ grade students, and there were 34 students enrolled in the class. There were 21 female students and 13 male students. 21 of the students have attended preparatory class education prior to their education at the ELT department. The students have also taken the course "Reading and Writing skills I" in the previous term.

\subsection{Research Design}

This study adopted an action research to improve the students' foreign language writing skills. Action research (AR) can be defined as an approach in which data are collected and interpreted through repeated cycles, which are defined in a clear way (Bailey, 2001). The researchers followed AR to enhance their students' writing performances as AR is a kind of self-reflective implementation carried out by language learners to develop their writing practices and insights on these practices by considering the contexts in which they are conducted (Burns, 2005). AR focuses on problematic points to accomplish developments during applications (Burns, 2009).

The researchers followed the four stages of planning, action, observation, and reflection proposed by Kemmis and McTaggaret (1986, in Burns, 2005; p. 244) and Sagor (2005). In planning stage, the researchers planned the cycles, criteria, duration, and reflection processes, which were followed in cycles. The criteria for peer editing were also defined at this stage. They involved two sections: general criteria and specific criteria. General criteria involved the aspects of a language such as vocabulary, grammar, spelling, coherence, cohesion, punctuation and orthographic control in writing. Specific criteria involved the points up to the writing topic of the week. In action stage, writing activities and peer editing processes were conducted. The writing activities lasted 8 weeks, and students were expected to submit 5 writing assignments in predefined different topics. After completing writing assignments, students edited their peers' assignments by using the checklist comprising the general and specific criteria designed for each assignment. This peer editing stage was repeated 3 times for each assignment by different peers. In observation stage, the researchers observed the processes in order to prevent any problem that may arise during peer editing processes. After completing peer editing processes, students submitted their finalized drafts to the instructor. Lastly, the reflections of students towards peer editing in foreign language writing classes were collected through a form. The cycles which were followed during this action research were schematized (Diagram 1) as follows: 


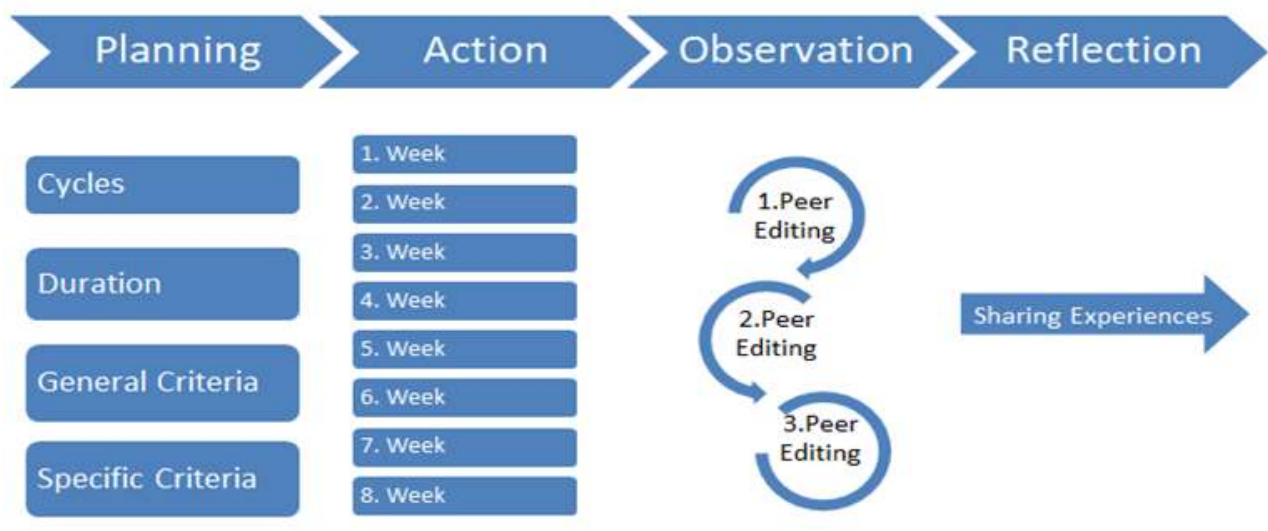

Diagram 1. Overall plan of the cycles

\subsection{Data Collection and Analysis}

The reflections of participants towards peer editing practices in writing classes were collected through a reflection form. The reflection form involved four themes as experiences in writing before peer editing, experiences in writing after peer editing, advantages of peer editing, and disadvantages of peer editing. Then, reflections from each participant were categorized under the appropriate themes, and reported descriptively. Each entry was coded by labeling the participant with ' $S$ ' (student) and a number to keep the participants' identity confidential.

\section{Results}

The first category reported the participants' reflections on writing before the peer editing cycles. Example entries from the participants for the first category as follows:

- Boring and non-exciting classes. (S2)

- The only thing that I used to do was writing, nothing else. (S4)

- I had difficulties in sentence structure and coherence of the paragraphs. (S10)

- I did not know how to write efficiently. (S15)

- I used to learn rules and forget applying them while writing. (S17)

- I did not know what criteria to apply while writing. (S22)

- I used to write long sentences with many mistakes. (S32)

The entries from the participants indicated that participants had problems in writing classes before peer editing cycles in terms of constructing sentences, following criteria, writing in an efficient way, interest in writing classes, etc.

The second category reported the participants' reflections on writing after the peer editing cycles. Example entries from the participants for the second category as follows:

- I learned how to see my mistakes and how to correct them. (S1)

- I started to write paragraphs in a correct way. I developed my vocabulary range. My paragraphs became more coherent. (S10)

- A different, entertaining, and didactic activity and experience. (S11) 
- In fact, this term taught us how to approach an assignment in an objective and correct way in a teacher's perspective. (S13)

- I learned how to write by following criteria. I focused on the structures of the essays. (S17)

- I can organize my essays in a correct way now. (S19)

- I began to see easily my mistakes in my writing assignments. (S20)

The entries from the participants reported that participants held positive views in writing classes after peer editing cycles in terms of following criteria, organizing writing, writing coherent paragraphs, recognizing their mistakes, beneficial experiences in writing classes, etc.

The third category reported the participants' reflections on the advantages of peer editing after the cycles. Example entries from the participants for the third category as follows:

- Essays were checked by the peers. Everybody evaluated them with a different perspective. A mistake that was disregarded by one peer was underlined by another peer. It was beneficial for me. (S3)

- We corrected our mistakes. We sorted out some problems about writing. We felt like a teacher. (S5)

- We saw our mistakes as well as others' through peer editing. It helped us in terms of grammar. (S10)

- I had chance of comparing my papers with my peers' papers. This was the most important advantage. (S14)

- Peer editing improved my writing. We learned new points, new vocabulary items. (S20)

- I learned many new ideas from my friends' paper while editing. (S23)

- I learnt how to evaluate a writing assignment. (S31)

The entries from the participants showed that participants think peer editing was beneficial in terms of evaluation by peers with a new perspective, comparing their papers with others' papers, learning new vocabulary items and new ideas, learning how to evaluate a writing assignment, etc.

The last category reported the participants' reflections on the disadvantages of peer editing after the cycles. Example entries from the participants for the fourth category as follows:

- Trying to correct paper without checking the appropriate usage caused confusions. (S3)

- They highlighted some true words or sentences as mistakes. (S15)

- Maybe the people who evaluated us do not know any grammar rules. It can be possible. I wish our teacher could control and show us our mistakes. (S17)

- Peers' behavior of finding mistakes demotivated me. (S22)

- Some of my peers marked unnecessary mistakes, and actually they were not mistakes. This made me angry about peer editing. (S25)

- They misjudged papers. They even crossed the words they did not know and tried to correct things that were already correct. (S26)

- As we are nearly at the same level, we made some problematic evaluations. (S33)

The entries from the participants reported that participants were not in favor of peer editing in terms of their peers' behaviors in dealing with mistakes without checking correct usages, and problematic evaluations due to being nearly the same proficiency levels.

\section{Discussion and Conclusion}


This study was designed as an AR and completed in ten weeks in the spring term of 2017-2018 academic year. Since AR is considered as a bridge between researchers and teachers, this study mainly focused on how prospective teachers can be encouraged to adapt it into their classroom practices. Thus, the underlying reason of this action research was to improve writing skills of the students studying at the ELT department through peer editing. The study followed planning, action, observation, and reflection cycles. In the first cycle, writing topics, peer editing checklists involving general and specific criteria were planned and introduced to the students. In the second cycle, eight weeks of writing process was carried out by the students. In the third cycle, students conducted peer editing processes through peer editing checklists, and the researchers observed these processes and helped them when necessary. In the fourth cycle, they reflected their experiences on peer editing.

The reflections from students mainly showed that they were in favor of peer editing in writing classes. This result supported previous studies in the literature. For example, Neff (2006) and Harutyunyan and Poveda (2018) reported that language learners benefited from analyzing their peers' papers. Likewise, Al-Nafiseh (2013) stated that peer editing improved students' writing skills by increasing their awareness on texts. Similarly, Garofalo (2013) expressed that the application of peer editing checklists contributes to second language learners by presenting them both writer and editor roles. Additionally, Diab (2010) and Hemati (2012) suggested the application of peer editing in writing classrooms for language teachers. However, the students expressed several negative views on peer editing applications in terms of their peers' insufficient knowledge on some grammar rules, vocabulary items, and problematic evaluations.

In conclusion, the results indicated that the participants were in favor of peer editing in EFL writing classes, and peer editing can be implemented as an effective way to enhance students' writing skills in foreign language learning. Peer editing in writing classes not only can help language learners to evaluate themselves through checklists but also it can present them different insights from their peers' papers in writing. Peer editing has positive effects on both developing learner autonomy, and cooperation and team work in the classroom. Moreover, it is highly motivating for the students, and it helps them to be aware of the criteria and rubric used for the assessment of writing. Though it has some challenges and drawbacks, it can be used as an alternative way in enhancing language learners' writing skills.

\section{Acknowledgements}

This study was presented orally in "GlobELT 2019 Conference: $5^{\text {th }}$ International Conference on Teaching and Learning English as an Additional Language" (11-14 April 2019, Merit Park Hotel, Kyrenia-Northern Cyprus).

\section{References}

Al-Nafiseh, K. I. (2013). Collaborative writing and peer-editing in EFL writing classes. Journal of Emerging Trends in Educational Research and Policy Studies (JETERAPS), 4(2), 236-245.

Amores, M. J. (1997). A new perspective on peer-editing. Foreign Language Annals, 30(4), 513-522.

Bailey, K. M. (2001). Action research, teacher research, and classroom research in language teaching. In M. Celce-Murcia (Eds). Teaching English as a second or foreign language (pp.489- 498). London: Thomson Learning.

Behjat, F., \& Yamini, M. ( 2012). Self- vs. peer-editing: one step forward from assessment to building EFL students' writing skill. Journal of Studies in Learning and Teaching English, 1(1), 65-85. 
Burns, A. (2005). Action research. In E. Hinkel (Eds). Handbook of research in second language teaching and learning (pp. 241-256). London: Lawrence Erlbaum Associates.

Burns, A. (2009). Doing action research in English language teaching: A guide for practitioners. NY: Routledge.

Byrd, D. R. (2003). Practical tips for implementing peer editing tasks in the foreign language classroom. Foreign Language Annals, 36(3), 435-441.

Diab, N. M. (2010). Effects of peer- versus self-editing on students' revision of language errors in revised drafts. System 38, 85-95.

Ekmekci, E. (2017). The flipped writing classroom in Turkish EFL context: A comparative study on a new model. Turkish Online Journal of Distance Education-TOJDE, 18(2), 151-167.

Finch, A. (2014). Participant perceptions of peer editing in an EFL freshman English program. Studies in British and American Language and Literature, 113(6), 299-326.

Garofalo, R. (2013). How the implementation of peer-editing checklists impacts the peer revision process in EFL writing classes. RitsIILCS, 24 (2), 143-159.

Göy, N. (2017). An action research on the development of self-regulated writing strategies of Turkish EFL students. Eurasian Journal of Applied Linguistics, 3(2), 191-204.

Harutyunyan, L., \& Poveda, M. F. (2018). Students' perception of peer review in an EFL classroom. English Language Teaching, 11(4), 138-151.

Hemati, M. (2012). The effect of teacher, peer, and self-editing on improving grammatical accuracy in EFL learners' writing. Diversité et Identité Culturelle en Europe, Retrieved June 20, 2019 from http://www.diacronia.ro/ro/indexing/details/A4026/pdf

Hengwichitkul, L. (2006). An analysis of errors in English abstracts translated by Thai university graduate students. (Unpublished master's thesis). Srinakharinwirot University, Bangkok, Thailand.

Kroll, B. (2001). Considerations for teaching an ESL/EFL writing course. In M. Celce-Murcia (Eds). Teaching English as a second or foreign language (pp.219-232).London: Thomson Learning.

Koboyashi, H., \& Rinnert, C. (2008). Task response and text constrcution across L1 and L2 writing. Journal of Second Language Writing, 17 (1), 7-29.

Kubota, R. (1998). An investigation of L1-L2 transfer in writing among Japanese university students: Implications for contrastive rhetoric. Journal of Second Language Writing, 7(1), 69-100.

Min, G., \& Xuemei, S. (2016). Study on training strategies for effective peer review. Cross-Cultural Communication, 12(12), 40-44.

Neff, P. E. (2006). Peer review in ESL/EFL writing courses: A look at five studies. Doshisha Studies in Language and Culture, 9(2), $345-371$.

Olshtain, E. (2001). Functional tasks for mastering the mechanics of writing and going just beyond. In M. Celce-Murcia (Eds). Teaching English as a Second or Foreign Language ( $3^{\text {rd }}$ ed.)(pp.207217).UK:Heinle\&Heinle.

Polio, C., \& Williams, J. (2009). Teaching and testing writing. In M. H. Long \& C. J. Doughty (Eds).The handbook of language teaching (486-517).UK: Wiley-Blackwell.

Rattanadilok Na Phuket, P., \& Othman, N. B. (2015). Understanding EFL students' errors in writing. Journal of Education and Practice, 6(32), 99-106. 
Reid, J. (2002). Writing. In Ronald Carter and David Nunan (eds). The Cambridge guide to teaching English to speakers of other languages (pp. 28-33). Cambridge: Cambridge University Press.

Ruegg, R. (2015). The relative effects of peer and teacher feedback on improvement in EFL students' writing ability. Linguistics and Education 29, 73-82.

Sadeghi, K., \& Baneh, M. D. (2012). Relationship between student self-monitoring, type of peer feedback and EFL writing performance. Theory and Practice in Language Studies, 2(5), 909-915.

Sagor, R. (2005). The action research guidebook: A four-step process for educators and school teams. CA: Corwin Press.

Sermsook, K., Liamnimitr, J., \& Pochakorn, R. (2017). An analysis of errors in written English sentences: A case study of Thai EFL students. English Language Teaching, 10(3), 101-110.

Strijbos, J. W., Narciss, S., \& Dünnebier, K. (2010). Peer feedback content and sender's competence level in academic writing revision tasks: Are they critical for feedback perceptions and efficiency? Learning and Instruction 20, 291-303.

Watcharapunyawong, S., \& Usaha, S. (2013). Thai EFL students' writing errors in different text types: The interference of the first language. English Language Teaching, 6(1), 67-78.

Zafar, A. (2016). Error analysis: a tool to improve English skills of undergraduate students. Procedia Social and Behavioral Sciences 217, $697-705$.

\section{İDE öğrencilerinin yazma becerilerini geliştirmenin bir yolu olarak akran değerlendirmesi: Bir eylem araştırması}

\section{$\ddot{O} \mathbf{z}$}

Yazmanın problemli doğasından yola çıkarak, bu çalışma bir İDE bölümündeki öğrencilerin yazma becerilerini geliştirmede akran değerlendirmesiyle bir eylem araştırması benimsemiştir. Bu çalışma eylem araştırmasının özel basamakları olan planlama, eylem, gözlem ve yansıtma yoluyla tasarlanmıştır. Planlama ve eylem basamaklarında, araştırmacılar döngüler süresince takip edilecek genel ve özel kıstasları belirlemişlerdir ve kıstasları bu doğrultuda uygulamışlardır. Gözlem basamağında, belirlenmiş döngülerdeki akran değerlendirme süreçleri gözlenmiştir. Bu basamakta araştırmacılar döngülerden faydalanmışlardır. Bu döngüler, akran değerlendirmesi süresince adım adım takip edilen uygulama süreçleridir. Yansıtma basamağında, katılımcıların yazma derslerindeki akran değerlendirmesi üzerine yansıtmaları bir form aracıllğıyla toplanmıştır. Katılımcılardan toplanan nitel veri, çalışma sonunda betimsel olarak analiz edilmiş ve raporlanmıştır. Yansıtmalar, yazma derslerinden öncesi ve sonrası, akran değerlendirmesinin yararları ve sakıncaları olarak sınıflandırılmıştır. Sonuç olarak, yazma derslerinde akran değerlendirmesi yabancı dil öğrenenleri olumlu yönde etkilemektedir ve akran değerlendirmesi IDE öğrencilerinin yazma becerilerini geliştirmede alternatif bir yol olarak kullanılabilir. 


\section{AUTHOR BIODATA}

Dr. Erkan Yüce is an instructor at School of Foreign Languages of Nevşehir Hacı Bektaş Veli University. He received his Ph.D. degree in English Language Teaching from Hacettepe University. The CEFR, program evaluation, ESP and CBI are among his fields of interest.

Assist. Prof. Dr. Bengü AKSU ATAÇ got her B.A. degree from Hacettepe University, English Language Teaching Department in 1994. She got her Master's Degree on ELT at Hacettepe University in 2001. She has completed her Ph.D. study in Ankara University, Department of Linguistics, Foreign Languages Teaching Programme in 2008. She worked as a lecturer at Atilim University, Faculty of Arts and Sciences between 1998 and 2013. She has been working in Nevşehir Hacı Bektaş Veli University, Faculty of Education, Foreign Languages Teaching Department since 2013. She is the Director of the School of Foreign Languages and Head of the ELT programme. Her professional interest areas are; language teaching, testing and assessment, Common European Framework of Refence for Languages, European Language Portfolio, authentic assessment, peace education and ELT for young learners. Dr. Aksu Ataç is a member of WCCI since 2004 and she is the president of WCCI Turkish Chapter and a member of the Board of WCCI International. 